Dhaka Univ. J. Biol. Sci. 24(1): 91-97, 2015 (January)

\title{
STRATEGIES FOR LEARNING AND ACADEMIC ACHIEVEMENT OF SECONDARY SCHOOL STUDENTS
}

\author{
Oli AHMED* AND MAHFuZa KHANAM \\ Department of Psychology, University of Dhaka, Dhaka-1000, Bangladesh \\ Key words: Control of learning beliefs, Self-efficacy, Learning strategies, Meta-cognitive \\ self-regulation, Academic achievement.

\begin{abstract}
Relationship between learning strategies and academic achievement was studied. In addition, it explored whether there were any differences between high and low achievers, males and females, and science and humanities' students in using learning strategies. Findings revealed that academic achievement was significantly correlated with academic self-efficacy, organization, and metacognitive self-regulation. High achievers differed from low achievers in using organization, and meta-cognitive self-regulation. In control of learning beliefs and rehearsal, significant gender differences exited. Science group students significantly differed from humanities students in academic self-efficacy, elaboration, and critical thinking.
\end{abstract}

\section{Introduction}

Academic achievement is the degree of academic learning by the person. It is the chief indicators in evaluating the education. It holds a prime importance in the field of education and is considered as the prerequisite for the progress of individuals. Learning strategies have strong correlation with it.

Learning strategies are the total effort that the students need to process, understand and adopt the information introduced in learning-teaching processes or in their individual preparation. These strategies range from simple study skills to complex thought processes. Most common and important learning strategies are rehearsal, elaboration, organization, critical thinking, meta-cognitive self regulation etc. Rehearsal is a simple learning strategy which stores information to be learned into working memory through processes of naming, repeating, and reciting material for learning. Elaboration is a learning strategy in which a learner or summarizes learning material to help the individual understand the material. Organization involves methods of outlining, taking notes, mapping or connecting key ideas in learning material. Critical thinking refers to the degree to which students report applying previous knowledge to new situations in order to solve problems, reach decisions, or make critical evaluations with

*Author for correspondence: <oliahmed_zhh@yahoo.com>. 
aspect to standards of excellence ${ }^{(1)}$. Meta-cognition is the awareness, knowledge and control of cognition. Self-regulated learning (SRL) refers to the self-directive processes and self-belief that enable learners to transform their mental abilities, such as verbal aptitude, into an academic performance skill, such as writing. There are three general processes that make up meta-cognitive self-regulatory activities: Planning, monitoring, and regulating. These motivational factors and learning strategies are predictors of academic achievement.

Rehearsal, elaboration, critical thinking, and meta-cognitive self-regulation as learning strategies have significant correlation with academic achievement ${ }^{(2-5)}$. Metacognitive self-regulation learning strategy is another strong predictor of academic achievement ${ }^{(6-8)}$.

Therefore, the aim of the present study was to investigate the relationship between learning strategies, which include rehearsal, elaboration, organization, critical thinking, and meta-cognitive self-regulation, and academic achievement of secondary school students. There are dearths of research in this context in Bangladesh. The present study would provide information about the secondary school students motivational beliefs, and learning strategies that they use, their strength and weakness in academic learning. Such information would be help to relevant authorities to design curriculum for students, and would also helpful to the teachers and guardians for taking psychological intervention to students for better advancement, and would also helpful to open new field of researches in Bangladesh to increase the quality of education. So the main objective of the study was to see the relationship between learning strategies and academic achievement of secondary school student. Special objectives were to compare the differences between high and low achiever students, to compare the level of gender difference and to compare the differences between science and humanities students.

\section{Materials and Methods}

The study sample comprised of 100 students from four schools of Netrakona district which were selected conveniently. From each school a total of 25 students were selected purposively from class IX and X. Among them, 92 respondents' responses were used finally. Of the respondents, $47.8 \%$ from class IX and $52.2 \%$ from class $X$, and $22.8 \%$ from science group, $6.5 \%$ from commerce group, and 70.7\% from humanities group. Among the respondents, $52.2 \%$ were female and $47.8 \%$ male. Duration of study hour per day ranged from 2 to $8 \mathrm{hrs}$. High and low achievers were categorized with their results. On the basis of the Gazette of the 'Ministry of Education', those who obtained G.P.A. 1 to 3 were considered as low achievers and those who obtained G.P.A. 3.01 to 5 were considered as high achievers.

For the present study, seven subscales of the the translated Bangla version ${ }^{(9)}$ of the 'Motivated Strategies for Learning Questionnaire' (MSLQ)(1) scale were used. Subscales 
were - rehearsal (item no. 39, 46, 59, 72), elaboration (item no. 53, 62, 64, 67, 69, 81), organization (item no. 32, 42, 49, 63), critical thinking (item no. 38, 47, 51, 66, 71), and meta-cognitive self-regulation (item no. $33,36,41,44,54,55,56,57,61,76,78,79$ ). The Cronbach Alpha reliability ranged from 0.52 (for help seeking) to 0.93 (for self efficacy for learning and performance). Correlation coefficients between original form of MSLQ and Bangla translation of the MSLQ ranged from 0.95 (for extrinsic goal orientation subscale) to 0.79 (for time and study management subscale). All subscales of the scale were significantly correlated with final grade (as reported by developers). The correlations of subscales of MSLQ with the subscales of the 'Academic Self-Regulated Learning Scale'(10) ranged from 0.10 to 0.34 . The cross-sectional survey design was used to collect necessary data for the present study.

The above instrument was administered on the study sample in classroom situation. Respondents were required to express their opinion concerning each item using a seven point scale, ranging from 'strongly disagree' (1) to 'strongly agree' (7). They expressed their opinion by putting tick $(\sqrt{ })$ mark on the appropriate response boxes those were best expression of their feelings.

\section{Results and Discussion}

To see the correlations among rehearsal, elaboration, organization, critical thinking, meta-cognitive self-regulation, and academic achievement, the collected data were subjected to the 'Pearson Product Moment Correlation' analysis. Results are shown in Table 1.

Table 1. Correlations among rehearsal (RHS), elaboration (ELB), organization (ORG), critical thinking (CT), meta-cognitive self-regulation (MSR), and academic achievement (AA).

\begin{tabular}{llllll}
\hline Variables & AA & RHS & ELB & ORG & CT \\
\hline RHS & 0.116 & & & & \\
ELB & 0.172 & $0.343^{*}$ & & & \\
ORG & $0.343^{* *}$ & $0.256^{*}$ & $0.413^{* *}$ & & \\
CT & 0.085 & $0.209^{*}$ & $0.369^{* *}$ & $0.400^{* *}$ & \\
MSR & $0.293^{* *}$ & $0.316^{* *}$ & $0.585^{* *}$ & $0.473^{* *}$ & $0.438^{* *}$ \\
\hline
\end{tabular}

${ }^{*} \mathrm{p}<0.05,{ }^{* *} \mathrm{p}<0.01$.

Table 1 indicates that academic achievement was significantly correlated with organization $(r=0.343, p<0.01)$, and meta-cognitive self-regulation $(r=0.293, p<0.01)$. Rehearsal was significantly correlated with elaboration $(\mathrm{r}=0.343, \mathrm{p}<0.01)$, organization $(\mathrm{r}=0.256, \mathrm{p}<0.05)$, critical thinking $(\mathrm{r}=0.209, \mathrm{p}<0.05)$, and meta-cognitive selfregulation $(r=0.316, p<0.01)$. Elaboration was significantly correlated with organization $(\mathrm{r}=0.413, \mathrm{p}<0.01)$, critical thinking $(\mathrm{r}=0.369, \mathrm{p}<0.01)$, and meta-cognitive selfregulation $(\mathrm{r}=0.585, \mathrm{p}<0.01)$. Organization was significantly correlated with critical 
thinking $(\mathrm{r}=0.400, \mathrm{p}<0.01)$, and meta-cognitive self-regulation $(\mathrm{r}=0.473, \mathrm{p}<0.01)$. Critical thinking was also significantly correlated with meta-cognitive self-regulation $(\mathrm{r}=$ $0.438, p<0.01$ ). All significant correlations were positive.

Significant correlations between academic achievement and organization, and metacognitive self-regulation were supported by previous studies ${ }^{(1,4,11)}$. In organizational strategy, learners impose structure on the material by dividing it into parts and identifying super ordinate-subordinate relationships. These relationships help the learners to easily memorize the contents. Students, who are using meta-cognitive selfregulation strategy, can monitor, direct, and regulate actions toward goals of information acquisition, expanding expertise, and self-improvement. They are cognizant of their academic strengths and weaknesses, and they have a repertoire of strategies they appropriately apply to tackle the day-to-day challenges of academic tasks.

Rehearsal, elaboration, and critical thinking were not significantly correlated with academic achievement. But, these were significantly correlated with meta-cognitive selfregulation. So, it can be inferred that these strategies have indirect effect on academic achievement. Chiu et al. found no significant correlation between elaboration and academic achievement ${ }^{(12)}$.

Results of the $t$ test to see the differences between low and high achiever students in learning strategies are presented in Table 2.

Table 2. Mean differences between low achiever and high achiever students in rehearsal, elaboration, organization, critical thinking, and meta-cognitive self regulation.

\begin{tabular}{|c|c|c|c|c|c|c|c|c|}
\hline \multirow[t]{2}{*}{ Variables } & \multicolumn{3}{|c|}{ Low achiever } & \multicolumn{3}{|c|}{ High achiever } & \multirow[t]{2}{*}{$\mathrm{df}$} & \multirow[t]{2}{*}{$\mathrm{t}$ value } \\
\hline & $\mathrm{N}$ & M & SD & $\mathrm{N}$ & M & SD & & \\
\hline Rehearsal & 32 & 22.88 & 10.79 & 54 & 23.31 & 3.89 & 90 & -0.272 \\
\hline Elaboration & 32 & 33.22 & 4.83 & 54 & 34.17 & 4.29 & 90 & -0.945 \\
\hline Organization & 32 & 19.41 & 4.92 & 54 & 21.59 & 3.91 & 90 & $-2.275^{*}$ \\
\hline Critical thinking & 32 & 21.31 & 4.42 & 54 & 21.83 & 4.44 & 90 & -0.526 \\
\hline $\begin{array}{l}\text { Meta cognitive self } \\
\text { regulation }\end{array}$ & 32 & 61.41 & 8.05 & 54 & 65.11 & 9.07 & 90 & $-1.966^{*}$ \\
\hline
\end{tabular}

Table 2 indicates that low and high achiever students were significantly differed in using organization ( $\mathrm{t}$ test score $=-2.275$ with $\mathrm{df} 84, \mathrm{p}<0.05$ ) and meta-cognitive selfregulation ( $\mathrm{t}$ test score $=-1.966$ with $\mathrm{df} 84, \mathrm{p}<0.05$ ) learning strategies. These score indicated that students who were high achiever using organization and meta-cognitive self-regulation strategies more than low achiever. These findings also support the findings from Table 1 where we found that organization, and meta-cognitive selfregulation significantly positively correlated with academic achievement. Simsek and 
Balaban reported that best predictor was meta-cognitive strategy and lowest was rehearsal( ${ }^{(4)}$.

Results of the $t$ test to see the level of gender differences in learning strategies are presented in Table 3.

Table 3 indicates significant mean differences between male and female students in rehearsal ( $\mathrm{t}$ test score $=-1.977$ with $\mathrm{df} 90, \mathrm{p}<0.05$ ). These score indicated that female students were more using rehearsal strategy than male students. It was in agreement with findings of Simsek and Balaban(4). He also found gender differences in critical thinking, organization, and meta-cognitive self-regulation. But, present study was failed to show gender differences in critical thinking, organization, and meta-cognitive selfregulation.

Table 3. Mean differences in rehearsal, elaboration, organization, critical thinking, and metacognitive self regulation by gender.

\begin{tabular}{|c|c|c|c|c|c|c|c|c|}
\hline \multirow[t]{2}{*}{ Variables } & \multicolumn{3}{|c|}{ Male } & \multicolumn{3}{|c|}{ Female } & \multirow[t]{2}{*}{$\mathrm{df}$} & \multirow[t]{2}{*}{ t-value } \\
\hline & $\mathrm{N}$ & $\mathrm{M}$ & SD & $\mathrm{N}$ & $\mathrm{M}$ & SD & & \\
\hline Rehearsal & 44 & 21.50 & 5.12 & 48 & 24.37 & 8.48 & 90 & $-1.977^{*}$ \\
\hline Elaboration & 44 & 32.79 & 5.23 & 48 & 34.29 & 3.86 & 90 & -1.57 \\
\hline Organization & 44 & 20.25 & 4.81 & 48 & 21.39 & 4.16 & 90 & -1.224 \\
\hline Critical thinking & 44 & 21.68 & 4.59 & 48 & 21.93 & 4.56 & 90 & 0.365 \\
\hline Meta cognitive self regulation & 44 & 61.77 & 9.46 & 48 & 64.25 & 8.37 & 90 & -1.657 \\
\hline
\end{tabular}
${ }^{*} \mathrm{p}<0.05$.

Results of the $t$ test to see the differences between science and humanities students in learning strategies are presented in Table 4.

Table 4. Mean differences between science and humanities students in rehearsal, elaboration, organization, critical thinking, and meta-cognitive self regulation.

\begin{tabular}{|c|c|c|c|c|c|c|c|c|}
\hline \multirow[t]{2}{*}{ Variables } & \multicolumn{3}{|c|}{ Science } & \multicolumn{3}{|c|}{ Humanities } & \multirow[t]{2}{*}{$\mathrm{df}$} & \multirow[t]{2}{*}{ t value } \\
\hline & $\mathrm{N}$ & M & SD & $\mathrm{N}$ & $\mathrm{M}$ & SD & & \\
\hline Rehearsal & 21 & 24.62 & 3.08 & 65 & 22.75 & 8.21 & 84 & 1.015 \\
\hline Elaboration & 21 & 35.48 & 4.45 & 65 & 33.14 & 4.62 & 84 & $2.022^{*}$ \\
\hline Organization & 21 & 22.00 & 4.55 & 65 & 20.18 & 4.48 & 84 & 1.056 \\
\hline Critical thinking & 21 & 23.57 & 2.74 & 65 & 21.22 & 4.81 & 84 & $2.128^{*}$ \\
\hline Meta cognitive self-regulation & 21 & 66.57 & 5.85 & 65 & 63.12 & 9.28 & 84 & 1.599 \\
\hline
\end{tabular}

*p $<0.05$.

Table 4 indicates significant mean differences between science and humanities students in elaboration ( $\mathrm{t}$ test score $=2.022$ with $\mathrm{df} 84, \mathrm{p}<0.05$ ), and critical thinking ( $\mathrm{t}$ test score $=2.128$ with $\mathrm{df} 84, \mathrm{p}<0.05)$. It indicated that students of science group used 
more elaboration and critical thinking strategies. Generally, science group is taken by high than low achiever students in Bangladesh. High achiever students use more learning strategies than low achiever students ${ }^{(4)}$. So, these differences between science students and humanities students might exist.

Findings of the present study suggested that for better academic achievement teachers and guardians may take some psychological interventions in using elaboration, organization, critical thinking, and meta-cognitive self regulation. Among strategies, meta-cognitive self regulated learning is the most effective learning strategy.

Present study recommended more experimental research is needed on the role of learning strategies on both cognitive and affective outcomes in technology-based learning environments. The results of the recommended studies may have great influences and serious implications both for educational researchers and practitioners in Bangladesh.

\section{References}

1. Pintrich P, D Smith, T Garcia and W McKeachie 1991. A Manual for the use of the Motivated Strategies for Learning Questionnaire (MSLQ). Ann Arbor, MI: University of Michigan, National Center for Research to Improve Postsecondary Teaching and Learning.

2. Burris S and BL Garton 2006. An investigation of the critical thinking ability of secondary agriculture students. Journal of Southern Agricultural Education Research 56(1): 18-29.

3. Diseth A and T Kobbeltvedt 2010. A median analysis of achievement motives, goals, learning strategies, and academic achievement. British Journal of Educational Psychology 80(4): 671687.

4. Simsek A and J Balaban 2010. Learning strategies of successful and unsuccessful university students, Contemporary Educatinal Technology 1(1): 36-45.

5. Li J and CKW Chun 2012. Effect of learning strategies on student reading literacy performance. The Reading Matrix 12(1): 30-38.

6. Isaacson RM and F Fujita 2006. Metacognitive knowledge monitoring and self-regulated learning: Academic success and reflections on learning. Journal of the Scholarship of Teaching and Learning 6(1): 39-55.

7. Kosnin AM 2007. Self-regulated learning and academic achievement in Malaysian undergraduates. International Education Journal 8(1): 221-228.

8. Crede M, SG Roch and UM Kieszczynka 2010. Class attendance in college: a meta-analytic review of the relationship of class attendance with grades and student characteristics. Review of Educational Research 80: 272-295.

9. Khanom M and O Ahmed 2014. The Translated Bangla Version of the Motivated Strategies for Learning Questionnaire. Department of Psychology, University of Dhaka.

10. Magno C 2010. Assessing academic self-regulated learning among Filipino college students: The factor structure and item fit. The International Journal of Educational and Psychological Assessment 5(1): 61-78. 
11. Adeyemo DA 2007. Moderating influence of emotional intelligence on the link between academic self-efficacy and achievement of university students. Psychology Developing Societies 19(2): 199-213.

12. Chiu MM, BWY Chow and CM Chang 2007. Universals and specifics in learning strategies: Explaining adolescent mathematics, science, and reading achievement across 34 countries. Learning and Individual Differences 17: 344-365.

(Manuscript received on 13 August, 2014; revised on 1 November, 2015) 